\title{
XMRV infection in human diseases
}

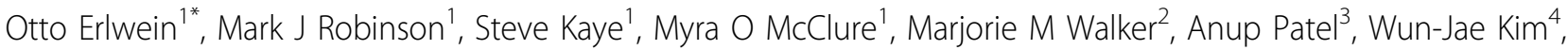 \\ Mongkol Uiprasertkul ${ }^{5}$, Ganesh Gopalakrishnan ${ }^{6}$, Takahiro Kimura', Kikkeri Naresh ${ }^{8}$ \\ From 15th International Conference on Human Retroviruses: HTLV and Related Viruses \\ Leuven and Gembloux, Belgium. 5-8 June 2011
}

The novel gammaretrovirus xenotropic murine leukemia virus-related virus (XMRV) was identified in human prostate cancer tissue in 2006, confirmed in 2009 and later linked to a second human condition chronic fatigue syndrome, CFS. These investigations, all carried out in the US, have not been reproduced in Europe or in China.

We found no evidence for XMRV infection in CFS. Moreover, we failed to find evidence of XMRV infection in UK prostate cancer patients and in prostate cancer tissue taken from patients in India, Korea, Thailand and Japan, or in cancers other than that of the prostate.

Our UK CFS patients were consistently XMRV-free. We did, however, generate false-positive results from prostate cancer patient tissue, despite the fact that the no-template controls in our PCR were consistently negative and the PCR for murine mitochondrial DNA was often also negative.

Sources of this contamination will be discussed in our presentation.
doi:10.1186/1742-4690-8-S1-A238

Cite this article as: Erlwein et al:: XMRV infection in human diseases. Retrovirology 2011 8(Suppl 1):A238.

\begin{abstract}
Author details
${ }^{1}$ Section of Infectious Diseases, Jefferiss Research Trust Laboratories, Imperial College London, London, W2 1PG, UK. ²Department of Histopathology, Imperial College London, London, W2 1PG, UK. ${ }^{3}$ Department of Urology, Imperial College Healthcare Trust, London, W2 1PG, UK. ${ }^{4}$ Department of Urology, College of Medicine, Personalised Tumor Engineering Research Centre, Chungbuk National University, Chungbuk, 361-763, Korea. ${ }^{5}$ Department of Pathology, Faculty of Medicine, Siriraj Hospital, Mahidol University, Bangkok, 10700, Thailand. 'Vedanayagam Hospital, RS Puram, Coimbatore,-641002, India. ${ }^{7}$ Department of Urology, Jikei University, School of Medicine 3-25-8, Nishi-Shinbashi, Minato-ku, Tokyo, Japan. ${ }^{8}$ Centre for Pathology, Hammersmith Hospital Campus, Imperial College Healthcare NHS Trust, London, UK.
\end{abstract}

Published: 6 June 2011

\footnotetext{
* Correspondence: o.erlwein@imperial.ac.uk

'Section of Infectious Diseases, Jefferiss Research Trust Laboratories, Imperial College London, London, W2 1PG, UK
}

Full list of author information is available at the end of the article
Submit your next manuscript to BioMed Central and take full advantage of:

- Convenient online submission

- Thorough peer review

- No space constraints or color figure charges

- Immediate publication on acceptance

- Inclusion in PubMed, CAS, Scopus and Google Scholar

- Research which is freely available for redistribution

Submit your manuscript at www.biomedcentral.com/submit

\section{() Biomed Central}

